\title{
STRATEGI BERSAING DAN CORE CAPABILITY PADA USAHA KONVEKSI DAN BORDIR
}

\author{
Madziatul Churiyah \\ E-mail: maziatul_c@yahoo.com
}

\begin{abstract}
Abstrak: Penelitian ini bertujuan mengeksplorasi strategi bersaing dan kemampuan inti yang dimiliki oleh usaha konveksi dan bordir "Arfad" Malang. Jenis penelitian merupakan penelitian kualitatif dan tekhnik pengumpulan data menggunakan wawancara, observasi, dokumentasi, dan diskusi terfokus (Focus Group Discussion) antara peneliti, pemilik, manajer operasional dan karyawan. Hasil penelitian menjelaskan bahwa strategi bersaing yang diterapkan adalah optimalisasi modal intelektual serta mempunyai beberapa kemampuan inti (core capability) yang terus dikembangkan.
\end{abstract}

Kata kunci: Strategi Bersaing, Kemampuan Inti

\section{PENDAHULUAN}

Perubahan yang terjadi dalam berbagai aspek lingkungan bisnis dan semakin ketatnya persaingan yang ada mengharuskan perusahaan untuk berfikir kreatif dan inovatif dalam menyiasati fenomena tersebut. Karena perlu disadari bahwa suatu usaha dibangun adalah memiliki tujuan bukan saja dalam jangka pendek yaitu untuk mendapatkan laba, tetapi lebih jauh lagi adalah usaha yang dibangun itu dapat bertahan dan berkembang dalam jangka panjang. Dalam kepentingan itu, maka diperlukan suatu langkah-langkah strategis guna memberikan suatu jaminan kepastian dalam menghadapi era persaingan dan perubahan lingkungan bisnis yang timbul.

Dengan adanya tekanan kompetitif dalam dunia bisnis, maka perusahaan dituntut untuk selalu memikirkan cara bagaimana perusahaan harus dapat menyesuaikan diri dan bahkan bisa mengatasi lingkungan yang senantiasa

mengalami perubahan-perubahan. Oleh karena itu perusahaan hendaknya memiliki kemampuan untuk mendeteksi trend yang muncul, memiliki kemampuan pengambilan keputusan dengan cepat dan akurat serta memiliki kecakapan untuk selalu mencari inovasi baru dalam menjalankan bisnisnya (Ulrich dalam Setyanto, 2004).

Melihat kenyataan diatas, maka perusahaan-perusahaan perlu memiliki kemampuan inti (Core Capability) yang kompetitif tanpa terkecuali pada berbagai skala usaha, baik itu usaha dengan skala besar maupun usaha-usaha yang berskala kecil dan menengah. Konsekuensi dari kompetisi yang semakin ketat cenderung akan menyebabkan tingkat keuntungan (rate of return) yang diperoleh perusahaan akan semakin menurun jika tidak dilakukan antisipasi dengan baik. Oleh karena itu upaya peningkatan daya saing usaha menjadi satu kebutuhan yang sangat mendesak dan sangat perlu untuk dilakukan.

Madziatul Churiyah, adalah Dosen Fakultas Ekonomi Universitas Negeri Malang 
Permasalahan peningkatan daya saing perusahaan dikaitkan dengan usaha kecil-menengah (UKM) menjadi hal yang sangat menarik dan penting untuk dikaji lebih lanjut. Ditengah ketangguhannya menghadapi krisis yang terjadi dalam perekonomian, serta kontribusinya yang besar dalam sektor perekonomian khususnya bagi penyerapan tenaga kerja dan pemerataan, usaha kecil-menengah sesungguhnya memiliki masalah yang sangat rumit dan mengakar, yaitu lemahnya kompetensi yang dimiliki pada berbagai aspek pengelolaan bisnisnya. Seperti penelitian yang dilakukan KADIN, diperoleh hasil beberapa faktor yang menjadi hambatan usaha kecil menengah untuk bisa maju (KADIN dalam Zulkieflimansyah dan Muhamad H., 2003), antara lain: (1) lemahnya sistem pembiayaan dan dukungan permodalan; (2) kurangnya kemampuan dalam melakukan akses pasar, daya saing pemasaran dan regulasi pasar domestik maupun global; (3) terbatas informasi sumber bahan dan panjangnya jalur distribusi serta lemah dalam kekuatan tawar menawar; (4) lemah dalam kemampuan teknologi; (5) kualitas sumber daya manusia masih lemah, yang meliputi aspek kompetensi, keterampilan, etos kerja, wawasan kewirausahaan dan standarisasi produk dan jasa; (6) birokrasi perijinan membutuhkan waktu relatif panjang; (7) keberadaan lembaga penjamin belum mampu melayani UKM secara optimal; (8) tidak berfungsinya secara baik lembaga promosi pemerintah.

Permasalahan-permasalahan yang telah dikemukakan diatas dihadapi juga oleh kelompok usaha garmen di Kota Malang khususnya usaha konveksi dan bordir "Arfad". Usaha konveksi dan garmen "Arfad" menghasilkan produk berupa: aneka macam bordir bahan kain untuk pakaian, baju koko, baju muslim, jilbab dan topi. Mempunyai tenaga kerja borongan dan harian sebanyak 40 orang dan tenaga tetap 10 orang yang direkrut dari tetangga yang membutuhkan pekerjaan dan bersedia dengan sistem kerjanya. Jenis usaha merupakan jenis usaha keluarga yang berdiri sejak tahun 1992, pemiliknya semula adalah (alm) bapak $\mathrm{H}$. M. Fadhil saat ini dilanjutkan oleh putra pertamanya yaitu Bpk. H. Ahsanul Ludzfi. Pemasaran dan distribusi produknya selain di Jawa Timur juga ke provinsi jambi, kalimantan dan Irian Jaya.

Permasalahan yang dihadapi usaha konveksi dan bordir "Arfad" sampai saat ini adalah sulit mendapatkan modal yang cukup terutama saat jumlah pesanan melebihi kecukupan modal yang tersedia, kurang memiliki kemampuan dalam melakukan akses pasar utamanya pasar luar negeri (ekspor) hal ini disebabkan karena mutu tekstil Indonesia yang masih belum bisa di terima di pasar internasional, desain pakaian, warna, ukuran dan bordir yang dihasilkan juga masih belum sesuai dengan konsumen internasional, lemah dalam pengelolaan usaha (manajemen usaha) termasuk didalamnya sumber daya manusia yang dimiliki mengingat usaha ini usaha keluarga dan tenaga kerjanya diambil dari tetangga sekitar yang belum tentu mempunyai keahlian dibidangnya, dan pemasaran secara tradisional.

Penelitian ini ingin mengeksplorasi aktivitas strategi usaha serta kemampuan inti (core capability) yang dimiliki konveksi dan bordir "Arfad" Malang dalam bersaing di pasar lokal maupun nasional dengan keterbatasan sumber daya yang dimiliki.

Membangun keunggulan kompetitif merupakan komponen utama dari perilaku strategis (Bamberger dan Bonacker, 1994). Oleh karena industry kecil 
dikarakterisasi dengan one man one management (Staley dan Morse, 1965). Thompson \& Strickland ( 2004:3) menjelaskan bahwa strategi perusahaan adalah kombinasi dari langkah-langkah yang kompetitif dengan pendekatan bisnis yang diterapkan manajer untuk memuaskan pelanggan, bersaing dengan sukses, dan mencapai tujuan obyektif. Tujuan dari pengembangan rencana strategis adalah menciptakan keunggulan kompetitif (competitive adventage) yaitu sekumpulan faktor yang membedakan perusahaan dari para pesaingnya dan memberikan posisi unik di pasar sehingga lebih unggul dari para pesaingnya. Keunggulan kompetitif merupakan faktor dimana suatu perusahaan dapat lebih unggul dari pesaingnya di dalam suatu lingkungan yang kompetitif (Hayden, 1986). Dari perspektif strategis, kunci bagi kesuksesan bisnis adalah pengembangan keunggulan kompetitif yang unik, yaitu keunggulan yang menciptakan nilai bagi pelanggan dan sukar ditiru oleh para pesaing. Perusahaan yang memiliki keunggulan kompetitif akan menjadi pemimpin dalam pasarnya serta dapat mencapai laba diatas rata-rata.

Pada tataran industry kecil Manajemen strategis dapat meningkatkan efektivitas usaha kecil, tetapi lebih dulu wirausahawan harus memiliki prosedur yang dirancang untuk memenuhi kebutuhan mereka dan sifat khusus bisnis mereka. Prosedur manajemen strategis untuk usaha kecil harus mencakup fitur-fitur berikut ini ( Zimmerer \& Scarborough, Wilson: 2008): 1)Menggunkan horizon perencanaan yang relative singkat-dua tahun atau kurang, 2) Tidak formal dan tidak terstruktur, pendekatan nonformal lebih ideal, 3) Mendorong peran karyawan maupun pihak luar untuk meningkatkan keandalan dan kreativitas rencana yang dihasilkan, 4) Jangan memulai dengan menetapkan tujuan, karena penetapan tujuan yang berlebihan pada awalnya akan mengganggu proses kreatif manajemen strategis, 5) Pertahankan fleksibilitas: kondisi penuh persaingan akan mengubah dengan amat cepat segala rencana apapun yang dianggap permanen, 6) Berfokus pada pemikiran strategis, bukan hanya pada perencanaan, dengan cara menghubungkan tujuan jangka panjang dan operasi rutin, 7) Membiarkan perencanaan menjadi proses yang terus berjalan karena bisnis dan lingkungan persaingan tempat perusahaan beroperasi akan terus menerus berubah.

Ada 2 teori keunggulan kompetitif di dalam literatur manajemen strategi yang selama ini banyak diikuti oleh para peneliti, yaitu teori berbasis Industrial Organization (I/O) yang disebut sebagai outside-in dan teori berbasis sumber daya (Resource-Based View atau $R B V$ ) yang disebut sebagai inside-out. Usaha kecil berada pada lingkungan usaha yang sangat tidak pasti, maka sangat sulit bagi usaha kecil untuk menerapkan pendekatan I/O untuk merencanakan strateginya karena akan memerlukan perencanaan strategi terus menerus mengikuti kondisi lingkungan yang tidak pasti tersebut. Sedangkan untuk mendayagunakan sumber daya yang dimilikinya (sesuai dengan pendekatan RBV) akan lebih mudah bagi usaha kecil karena yang dibutuhkan adalah kapabilitas dalam pendayagunaan sumber daya tersebut. Dalam pendekatan berbasis sumber daya, sumber daya dalam suatu perusahaan dapat diklasifikasikan ke dalam keuangan, sumber daya fisik, manusia , organisasi dan teknologi (Man: 2001 dalam Chew, et all 2008). Namun, sumber daya sendiri tidak bisa menjadi keunggulan kompetitif kecuali mereka terorganisir menjadi kemampuan (capabilities). Kemampuan inti (core capability) merupakan dimensi potensi daya saing dari kinerja perusahaan (Chew, et all 2008). 
Kemampuan inti (core capability) adalah serangkaian kemampuan unik yang dikembangkan oleh perusahaan dalam bidang-bidang utama, seperti kualitas, layanan pelanggan, inovasi, pembinaan tim, fleksibilitas, cepat tanggap, dan lainlain yang lebih dari yang lain, sehingga bisa mengungguli pesaingnya( Zimmerer et all., 2008).

Umumnya, perusahaan mengembangkan kompetensi inti ini tidak lebih dari lima atau enam bidang. Kompetensi inti menjadi dasar bagi keunggulan kompetitif perusahaan dan biasanya bertahan cukup lama. Pasar, pelanggan, dan pesaing dapat berubah tetapi kompetensi inti perusahaan dapat lebih tahan lama, yang menjadi landasan bagi segala sesuatu yang dilakukan oleh perusahaan tersebut. Agar efektif, kompetensi inti haruslah sukar ditiru oleh pesaing, dan harus menyediakan manfaat yang dirasa penting bagi pelanggan.

Core capability merupakan potensi daya saing dari kinerja perusahaan (Chew, et all. 2008). Hall (1993) menyatakan bahwa keunggulan kompetitif yang berkelanjutan dihasilkan dari kepemilikan perbedaan kemampuan (capability) yang relevan, yang terkait dengan sumber daya tidak berwujud, termasuk hak milik, rahasia dagang, jaringan dan reputasi perusahaan. Rangone (1999) mengembangkan sebuah model di mana kinerja yang unggul dalam UKM didasarkan pada kemampuan inovasi, kemampuan produksi dan kemampuan pasar.

Kompetensi inti untuk usaha kecil sering kali berkaitan dengan keunggulan di bidang ukuran perusahannya, misalnya kelincahan, kecepatan, kedekatan dengan pelanggan, pelayanan yang lebih baik dan kemampuan berinovasi. Singkatnya, ukurannya yang kecil membuat mereka dapat melakukan sesuatu yang tidak mungkin dilakukan oleh perusahaan besar. Kunci kesuksesannya adalah membangun strategi berdasarkan kompetensi-kompetensi inti tersebut dan kemudian mengkonsetrasikan semua itu untuk memberikan pelayanan dan nilai yang unggul kepada pelanggan sasarnnya.

\section{METODE}

Penelitian ini merupakan penelitian deskriptif-kualitatif. Moleong (2002: 3) menyatakan "metodologi kualitatif" sebagai prosedur penelitian yang menghasilkan data deskriptif berupa kata-kata tertulis atau lisan dari orangorang dan perilaku yang dapat diamati. Penelitian ini dilakukan pada usaha konveksi dan bordir "ARFAD" Malang yang berlokasi di Jl. Zainal Arifin (Kudusan) No. 83 Malang, Jl. Kol. Sugiono 229 Malang, dan Jl. Raya Muharto 73 Malang. Tekhnik pengumpulan data dengan menggunakan wawancara dengan pemilik, observasi, dokumentasi, dan diskusi terfokus (Focus Group Discussion) antara peneliti, pemilik, manajer operasional dan karyawan. Tekhnik analisis data yang digunakan adalah tekhnik analisis data kualitatif yaitu dari reduksi data, penyajian data, dan penarikan kesimpulan. Pengecekan keabsahan data menggunakan trianggulasi data yaitu untuk menguji kredibilitas data dilakukan dengan cara mengecek data kepada sumber yang sama dengan teknik yang berbeda (Sugiyono, 2008:127). Jadi, misalnya data diperoleh dengan wawancara, lalu untuk menguji kebenaran data maka dicek menggunakan observasi dan dokumentasi. 


\section{PEMBAHASAN}

Setiap perusahaan pasti menghadapi kekuatan lingkungan persaingan yang cepat berubah, dan ke depan pemilik bisnis UMKM umumnya, khususnya usaha konveksi dan bordir "ARFAD" dihadapkan pada perubahan dan ketidakpastian yang semakin besar. Mulai dari perubahan kondisi politik dan cepatnya kemajuan teknologi sampai pasar global yang semakin keras persaingannya dan munculnya pasar-pasar baru. Hal ini ditandai semakin banyaknya garment luar negeri masuk ke Indonesia dengan harga yang murah dengan model penjualan on line tentu menjadi ancaman sekaligus tantangan bagi usaha konveksi dan bordir "ARFAD". Walaupun gejolak pasar ini menciptakan berbagai tantangan, hal ini juga menciptakan peluang bagi usaha konveksi dan bordir "ARFAD" yang memiliki strategi tepat untuk memanfaatkan gejolak tersebut. Yang penting adalah keinginan wirausahawan untuk beradaptasi, menciptakan perubahan, dan bereksperimen dengan model bisnis baru. Hal ini sejalan dengan CEO American Express Ken Chelnut dalam (Zimmerer \& Scarborough, Wilson: 2008) “ bukan (perusahaan) yang paling kuat atau yang paling pandai akan bertahan hidup, tetapi perusahaan yang paling bisa beradaptasi dengan perubahan."

Strategi bersaing yang diterapkan usaha konveksi dan bordir "ARFAD" berdasarkan hasil wawancara dengan pemilik dan manajemen operasional adalah sebagai berikut:

"Modal kami pas-pasan, kredit ke bank bunganya tinggi, mau bersaing dengan perusahaan besar tentu tidak mungkin, tapi kita harus melakukan tindakan nyata agar usaha ini terus berjalan dan bisa menghidupi 50 karyawan kami, sehingga kami menggunakan ilmu yang kami punya"

Dari hasil wawancara dengan pemilik tersebut tersirat bahwa strategi bersaing yang dilakukan sebenarnya sudah dilakukan walaupun dengan keterbatasan sumber daya modal dan sumber daya manusia. Lebih lanjut manajer operasional menjelaskan bahwa:

"Strategi bisnis yang diterapkan selama ini adalah kami selalu terus berinovasi, pelayanan terhadap pelanggan yang memuaskan dan tepat waktu, serta kami mempunyai tenaga kerja yang berbakat dan kreatif, walaupun mereka hanya lulusan SMP bahkan SD tapi ada nilai sosial yang kami yakini yaitu menolong tetangga sekitar yang tidak punya pekerjaan".

Pernyataan di atas secara jelas bahwa usaha konveksi dan bordir "ARFAD" menggunakan modal intelektual sebagai sumber keunggulan kompetitif di pasar. Hal ini seperti yang dijelaskan Zimmerer \& Scarborough, Wilson (2008) bahwa modal intelektual terdiri dari tiga komponen yaitu 1) Modal manusia (human capital): bakat, kreativitas, ketrampilan, perencanaan, inovasi yang dikembangkan dengan semangat berusaha yang dicapai orang-orang dalam perusahaan, 2) Modal structural (structural capital): akumulasi pengetahuan dan pengalaman yang dimiliki perusahaan. Bentuk modal ini bisa mencakup pemrosesan, peranti lunak, hak paten, hak cipta, dan mungkin yang terpenting pengetahuan dan pengalaman 
orang-orang dalam perusahaan, 3) Modal pelanggan ( customer capital); basis pelanggan yang mapan, reputasi positif, hubungan yang terus menerus, dan goodwill yang dibangun oleh perusahaan sepanjang waktu dengan pelanggannya

Semakin lama wirausahawan semakin menyadari bahwa modal yang tersimpan dalam tiga bidang ini menjadi landasan bagi kemampuan mereka untuk bersaing secara efektif dan bahwa mereka harus mengelola modal tak berwujud ini secara hati-hati. Setip perusahaan menggunakan ketiga komponen ini dalam strateginya, tetapi masing-masing perusahaan memberikan penekanan pada komponen yang berbeda.

Revolusi pengetahuan ini akan menimbulkan bencana bagi perusahaanperusahaan yang tidak siap, namun akan memberikan peluang yang besar bagi wirausahawan yang memiliki strategi mengeksploitasi peluang ini. Pakar manajemen Jack Welch menjelaskan bahwa modal intelektual adalah segalanya. Mengeluarkan ide-ide dari orang-orang merupakan keharusan bila kita ingin menang, akan tetapi dalam praktiknya mengeluarkan ide tidak semudah yang dilihat. Kuncinya adalah mendorong karyawan menghasilkan banyak ide, sekaligus menyadari bahwa hanya beberapa ide yang terbaik yang akan dipertahankan.

Tidak hanya itu saja manajemen usaha ini terus berbenah dan melihat siapa pesaing potensi mereka. Seperti petikan wawancara berikut ini:

"kami selalu waspada dengan gerakan pesaing, sehingga kami perlu menggunakan program kecerdasan bersaing, tidak perlu mahal kami cukup mengikuti pameran UMKM lalu mengamati siapa saja saingan utama kami dan bagaimana mereka menawarkan produknya. Dari situ kami bisa terus berbenah dan berinovasi"

Peneliti baru menyadari yang semula mengira usaha konveksi dan bordir "ARFAD" dimanajemeni dengan sederhana ternyata lebih dari sederhana dalam hal strategi bersaingnya. Menggunakan program kecerdasan bersaing (competitive intelegence) sudah dilakukan walaupun dengan cara yang sederhana dengan tujuan 1)menghindari kejutan yang berasal dari strategi dan taktik baru pesaing, 2) mengidentifikasi calon pesaing baru, 3) memperbaiki saat yang tepat untuk bereaksi terhadap tindakan pesaing, 4) mengantisipasi tindakan strategis berikutnya dari pesaing.

Hasil survey yang diadakan National Small Business Poll tahun 2003 (Dennis, 2003) menunjukkan bahwa strategi kompetitif terbesar yang dilakukan UKM di Amerika adalah menyediakan kualitas yang terbaik (86,3\%), menawarkan layanan yang lebih baik $(83,4 \%)$ disusul kemudian mempertahankan overhead seminimal mungkin (51\%) dan menerapkan tekhnologi semaksimal mungkin (48,5\%). Dari survey tersebut di atas usaha konveksi dan bordir "Arfad" dapat mengambil pelajaran untuk diterapkan di usahanya dalam rangka memenangkan persaingan usahanya

Tujuan dari pengembangan rencana strategis adalah menciptakan keunggulan kompetitif (competitive adventage) yaitu sekumpulan factor yang membedakan perusahaan kecil dari para pesaingnya dan memberikan posisi unik di pasar sehingga lebih unggul dari para pesaingnya. Dari perspektif strategis, kunci bagi kesuksesan bisnis adalah pengembangan keunggulan kompetitif yang unik, yaitu keunggulan yang menciptakan nilai bagi pelanggan dan sukar ditiru oleh para 
pesaing. Perusahaan yang memiliki keunggulan kompetitif akan menjadi pemimpin dalam pasarnya serta dapat mencapai laba diatas rata-rata.

Membangun keunggulan kompetitif tidaklah cukup, kunci kesuksesannya adalah membangun keunggulan kompetitif yang berkelanjutan (sustainable). Dalam jangka panjang, perusahaan memperoleh keunggulan kompetitif yang berkelanjutan melalui kemampuannya mengembangkan seperangkat kompetensi inti sehingga perusahaan tersebut mampu melayani pelanggan sasarannya dengan lebih baik dibandingkan dengan pesaingnya. Kompetensi inti (core competencies) adalah serangkaian kemampuan unik yang dikembangkan oleh perusahaan dalam bidang-bidang utama, seperti kualitas, layanan pelanggan, inovasi, pembinaan tim, fleksibilitas, cepat tanggap, dan lain-lain yang lebih dari yang lain, sehingga bisa mengungguli pesaingnya.

Umumnya, perusahaan mengembangkan kompetensi inti ini tidak lebih dari lima atau enam bidang. Kompetensi inti menjadi dasar bagi keunggulan kompetitif perusahaan dan biasanya bertahan cukup lama. Pasar, pelanggan, dan pesaing dapat berubah tetapi kompetensi inti perusahaan dapat lebih tahan lama, yang menjadi landasan bagi segala sesuatu yang dilakukan oleh perusahaan tersebut. Agar efektif, kompetensi inti haruslah sukar ditiru oleh pesaing, dan harus menyediakan manfaat yang dirasa penting bagi pelanggan.

Kompetensi inti yang bisa dibangun oleh Usaha konveksi dan bordir "Arfad" berdasarkan observasi, pengamatan dan wawancara adalah sebagai berikut: 1) Karena ukuran perusahaanya yang relative kecil sehingga kemampuan inti yang bisa diandalkan adalah kelincahan, kecepatan, kedekatan dengan pelanggan, pelayanan yang lebih baik dan kemampuan berinovasi. Singkatnya, ukurannya yang kecil membuat mereka dapat melakukan sesuatu yang tidak mungkin dilakukan oleh perusahaan besar. Kunci kesuksesannya adalah membangun strategi berdasarkan kompetensi-kompetensi inti tersebut dan kemudian mengkonsetrasikan semua itu untuk memberikan pelayanan dan nilai yang unggul kepada pelanggan sasarannya, 2) Usaha konveksi dan bordir "Arfad" memiliki jenis produk yang lebih sedikit, basis pelangganyang lebih jelas, hubungan yang baik terjalin dengan pelanggannya, dan pasar geografis yang lebih khusus dibandingkan perusahaan besar lainnya. Oleh karena itu pemilik mampu mempertahankan hubungan dekat dengan pasar mereka, sehingga mereka memiliki pengetahuan yang berharga mengenai cara terbaik untuk melayani kebutuhan dan keinginan pelanggan mereka, 3) Kesederhanaan struktur organisasinya yang ada pemilik usaha ini selalu berhubungan dengan karyawan setiap hari, sering bekerja bersama-sama sehingga mereka dapat mengkomunikasikan tindakan strategi secara langsung. Oleh sebab itu usaha konveksi dan bordir "Arfad" harus menyadari bahwa perencanaan strategis lebih alamiah bagi mereka daripada usaha besar yang birokrsinya berlapis-lapis dan operasinya yang menyebar ke berbagai wilayah.

Mengembangkan kompetensi inti tidak selalu harus mengeluarkan biaya yang besar, akan tetapi wirausahawan dituntut harus menggunakan kreativitas, imajinasi dan visi untuk menentukan hal-hal terbaik dan terpenting yang dapat dilakukan perusahaan terhadap pelanggan sasarannya. Perusahaan memiliki sejumlah cara untuk menciptakan keunggulan kompetitif, tetapi membangun strategi perusahaan disekitar kompetensi inti menyebabkan bisnis dapat memperoleh daya saing yang berkelanjutan atas pesaingnya. 


\section{KESIMPULAN}

Usaha kecil perlu menyadari sekecil apapun kemampuan inti (core capability) yang dimilikinya karena pada dasarnya masing-masing usaha mempunyai kemampuan inti. Jika kemampuan inti ini dikembangkan dalam jangka panjang akan menjadikan keunggulan strategi bersaing bagi usaha tersebut. Membangun keunggulan kompetitif tidaklah cukup, kunci kesuksesannya adalah membangun keunggulan kompetitif yang berkelanjutan (sustainable).

Saran yang direkomendasikan adalah agar usaha kecil ini bersaing secara berkelanjutan maka perlu ada peran pemerintah untuk membina dan mengembangkan usaha kecil sehingga kemampuan inti yang dimiliki bisa berkembang menjadi sebuah keunggulan bersaing bagi usaha tersebut juga bagi produk unggulan daerah.

\section{DAFTAR PUSTAKA}

Bamberger, I., Bonacker, R.1994. Strategies of Small an d Medium-sized Enterprises and Their Measurement. in Bamberger, I. (Ed.), Product/Market Strategies of Small and Medium-Sized Enterprises. Aldershot: Avebury.

Chew, Yan, Cheah. 2008. Core Capability and Competitive Strategy for Construstion SMEs in China. Chine Management Studies. Emerald Group Publishing Limited. Vol 2 No. 3.

Dennis, J William. 2003. National Small Business Poll: Competition. Washington DC: National Federation of Independent Businesses. Vol.3. Isu 8 P.1 (diakses 18 Februari 2012)

Hall, R. 1993. A framework linking intangible resources and capabilities to sustainable competitive advantage. Journal Strategic Management. Vol. 14 No. 8, pp. 607-18 (diakses 12 April 2012)

Hayden, C.L.1986. The Handbook of Strategic Enterprise. The Free Press: New York, NY.

Hunger, J. D. and Wheelen, T. L,. 2001. Strategic Management.1996. Fiveth Editions. Addison-Wesley Publishing Company, Inc. Agung J. (penterjemah).2001. Manajemen Strategis. Andi.Yogyakarta.

Moleong, L.J. 2002. Metodologi Penelitian Kualitatif. Cetakan ke-16. Bandung: Rosda Karya. 
Mulyadi, 2001. Balanced Scorecard. Alat Manajemen Kontemporer untuk Pelipatganda Kinerja Keuangan Perusahaan. Edisi kedua. Jakarta: Salemba Empat..

Pearce \& Robinson, 1997, Strategic Management. Richarrd D. Irwin, Inc. 1996. Maulana A., Saputra L. Dan Sularso E. (penterjemah). 1997. Manajemen Strategik : Formulasi, Implementasi, dan Pengendalian. Jakarta: Binarupa Aksara.

Rangone, A. 1999. A resource-based approach to strategy analysis in smallmedium sized enterprises. Small Business Economics Journal, Vol. 12, pp. 233-48. (diakses 12 April 2012).

Staley, E., Morse, R., 1965. Modern Small Industry for Developing Countries. McGraw Hill: New York.

Sugiyono. 2008. Memahami Penelitian Kualitatif. Bandung : CV Alfabeta

Thompson, A Arthur and Stricklan Aj. 2004, Strategic Management; Case an Consept. New York: Irwin MC, Grawhill.

Zimmerer, Scarborough, Wilson. 2008. Essentials of Entrepreneurship and Small Business Management, terjemahan. Jakarta: salemba Empat 